\title{
One and a half ventricular repair as an alternative for hypoplastic right ventricle
}

\author{
Operação de um ventrículo e meio como uma alternativa para o ventrículo direito hipoplásico
}

\author{
Miguel Angel MALUF ${ }^{1}$, Antonio Carlos CARVALHO², Werther Brunow CARVALHO ${ }^{3}$
}

RBCCV 44205-1216

\section{Resumo}

Objetivo: Pacientes com cardiopatia congênita complexa e caracterizada por hipoplasia do ventrículo direito têm uma opção de correção paliativa com a operação de um ventrículo e meio.

Métodos: De julho de 2001 a março de 2009, nove pacientes (idade média de 5,2 anos, variando de 3 a 9 anos), com hipoplasia do ventrículo direito, foram submetidos à correção com a técnica de um ventrículo e meio. Os diagnósticos pré-operatórios foram: atresia pulmonar com septo ventricular intacto, em seis casos, e anomalia de Ebstein, em três casos. Seis pacientes tiveram derivação cavo-pulmonar bidirecional (operação de Glenn) prévia. A abordagem cirúrgica foi realizada com circulação extracorpórea e os defeitos intracardíacos foram corrigidos: fechamento do defeito do septo atrial (nove casos), reconstrução da via de saída do ventrículo direito com prótese pulmonar porcina (sete casos); plástica da valva tricúspide (três casos).

Resultados: Houve um $(\mathbf{1 1 , 1 \% )}$ óbito. Todos os pacientes receberam alta hospitalar em boas condições clínicas. Um paciente apresentou estenose pulmonar distal à prótese, sendo necessária a reintervenção cirúrgica. Houve um (12,5\%) óbito tardio, após a reoperação. Sete $(77,8 \%)$ pacientes foram seguidos por período médio de 39,8 meses (intervalo de 16 meses para 8,4 anos) e se encontram em boas condições clínicas.

Conclusões: $O$ tratamento cirúrgico de cardiopatias congênita, na presença de um ventrículo direito hipoplásico, por meio da operação de um ventrículo e meio, tem menor risco cirúrgico que a correção biventricular, mantendo o átrio direito com baixa pressão, fluxo sanguíneo pulmonar pulsátil e melhora da saturação sistêmica de oxigênio. Os resultados

1. Professor Livre Docente; Prof. Adjunto.

2. Professor Titular, Disciplina de Cardiologia.

3. Professor Titular, Departamento de Pediatria - FMUSP)

Trabalho realizado na Disciplina de Cirurgia Cardiovascular da UNIFESP - EPM, São Paulo, SP, Brasil. de curto e médio prazo são satisfatórios; porém será necessário um maior tempo de seguimento para provar a eficácia desta abordagem cirúrgica a longo prazo.

Descritores: Cardiopatias congênitas/cirurgia. Implante de prótese de valva/métodos. Criança. Atresia pulmonar. Anomalia de Ebstein.

\section{Abstract}

Objective: Patients with complex congenital heart disease, characterized by right ventricle hypoplasia, had a palliative surgical option with one and a half ventricular repair.

Methods: From July 2001 to March 2009, nine patients (mean age 5.2 years, range 3 to 9 years) with hypoplastic right ventricle, underwent correction with one and a half ventricle technique. Preoperative diagnoses included: pulmonary atresia with intact ventricular septum, in six and Ebstein's anomaly, in three cases. Six patients had bidirectional cavo-pulmonary shunt (Glenn operation) previously. The surgical approach was performed with cardiopulmonary bypass to correct intracardiac defects: atrial septal defect closure (nine cases); right ventricle outlet tract reconstruction with porcine pulmonary prosthesis (seven cases); tricuspid valvuloplasty (three cases).

Results: There was one (11.1\%) hospital death. All the patients left the hospital in good clinical conditions. One patient presented pulmonary stenosis at distal prosthesis anastomosis and needed surgical correction. There was one $\mathbf{( 1 2 . 5 \% )}$ late deaths after reoperation. At mean follow-up of 39.8 months (range 16 months to 8.4 years) seven patients are alive in functional class $I$ (NYHA).
Endereço para correspondência: Miguel Maluf. Al. dos Anapurus, 1580/73 - Moema - São Paulo, SP, Brasil. CEP: 04087-005.

E-mail:miguelmaluf@gmail.com 
Conclusions: Surgical treatment of congenital cardiac anomalies in the presence of a hypoplastic right ventricle by means of one and a half ventricle repair has the advantages of reducing the surgical risk of biventricular repair compared to the Fontan circulation; it maintains a low right atrium pressure, a pulsatile pulmonary blood flow and improves the systemic oxygen saturation with short and

\section{INTRODUCTION}

Since the original contributions of Billingsley et al. [1] to the one and a half ventricle concept in patients with hypoplastic right ventricle, the indications for this type of repair have expanded to cover a variety of anomalies that feature a functionally abnormal right ventricle that would not be able to cope with the entire pulmonary circulation.

In recent years, the tendency has been to submit such patients to the so-called "one and a half ventricle repair". In this procedure, the heart is surgically septated. This might include one or more of the following intracardiac procedures: atrial septal defect closure, ventricular septal defect closure, atrioventricular canal repair and removal of the Rastelli type left ventricular - aortic valve baffle and the right ventricular - pulmonary artery conduit, thus, creating a superior cavopulmonary shunt.

The latter component of the procedure eliminates all systemic-pulmonary mixing and provides preload reduction for the limited right heart, thereby, avoiding right heart failure.

Patient selection for the one and a half ventricle repair comes under consideration in two specific clinical border zones. In one, the patient is a borderline candidate for the two ventricle repair, and the surgeon "backs off" to the one and a half ventricle repair to avoid postoperative right heart failure. Examples might include the patient with pulmonary atresia and intact ventricular septum with a right ventricle that is reasonably well developed but demonstrates morphological and/or physiological characteristics. At the other clinical border zone, the patient is clearly not a medium-term promising results. Longer follow-up is needed to prove the efficacy of such a repair in the long term.

Descriptors: Heart defects, congenital/surgery. Heart valve prosthesis implantation, methods. Child. Pulmonary atresia. Ebstein anomaly. candidate for the two ventricle repair, and the focus over the course of the patient's life has been toward achieving a Fontan operation; however, the internal morphology of the heart does allow a surgical septation [2].

The operation consists of a superior cavopulmonary anastomosis combined with the connection of the dysfunctional ventricle to the pulmonary artery through either a right ventricle outlet tract (RVOT) remodeling and the atrial septal defect is closed, in order to allow for desaturated inferior vena cava blood to enter the dysfunctional ventricle and flow to the pulmonary arteries.

The one and a half ventricle repair can be considered the last stage of the functional single ventricle pathway, in that the systemic and pulmonary circulations are entirely separated, and there is no compelling reason to perform a more traditional Fontan operation. A fenestrated one and a half ventricle repair can be performed in patients with significant risk factors, and consists of a superior cavopulmonary anastomosis with connection of the dysfunctional ventricle to the pulmonary arteries, along with a 4-5 mm snared fenestration in the atrial septum.

\section{METHODS}

\section{Study population}

From July 2001 to March 2009, nine patients (mean age 5.2 years, range 3 to 9 years) with preoperative diagnoses: pulmonary atresia-intact ventricular septum in (PA - IVS) in six and Ebstein's anomaly of tricuspid valve (TV) in three (Table 1).

Table 1. Preoperative characteristics of patients.

\begin{tabular}{lcc}
\hline Characteristics & $\begin{array}{c}\text { Patients } \\
\text { Mean (range) }\end{array}$ & $\begin{array}{c}\text { "Z” score Tric. valve } \\
\text { Mean (range) }\end{array}$ \\
\hline Age (years) & $5.2(3-9)$ & \\
Male & $5(55 \%)$ & $-3(-2$ to -4$)$ \\
PA- IVS & $6(66 \%)$ & $+3(+1$ to +4$)$ \\
Ebstein's Anomaly & $3(33 \%)$ & \\
Modified B-T shunt plus surgical pulmonary valvotomy & $6(66 \%)$ & \\
Previous BCPS & $6(66 \%)^{*}$ & \\
\hline
\end{tabular}

*Patients with PA-IVS; PA-IVS = pulmonary atresia with intact ventricular septum; B-T = Blalock Taussig; BCPS

= bidirectional cavopulmonary shunt; Tric = tricuspid 


\section{Right ventricle's morphology}

The sizes of the right ventricle, tricuspid valve, and pulmonary valve were assessed by echocardiography and angiography. The annular diameters of the tricuspid valve were measured by 2-dimensional echocardiography and during the operation with the aid of Hegar dilators, and the "Z" score was calculated [2]. Patients with "Z" scores lower than -4.5 and with diastolic volumes less than $45 \%$ of predicted of normal were treated as having univentricular hearts.

\section{Echocardiographic measurements}

Patients were submitted to Doppler-echocardiogram study to perform the preoperative diagnostic of the cardiac defects, in the neonatal stage and seriate echocardiogram during the follow-up, after palliative procedures.

The "Z" score of tricuspid valve was performed in all cases: In PA w/ IVS, the mean value of "Z" was -3 (range 2 to -4$)$ and in the Ebstein anomaly, the mean value of " $Z$ " was +3 (range +2 to +4 ).

\section{Cardiac angiography}

The cardiac catheterysm was performed in all patients with PA - IVS to study the RV: 1- Morphology: presence of the three segments: inlet, trabecular and infundibular portion and coronary artery circulation (anomalies, fistulae,

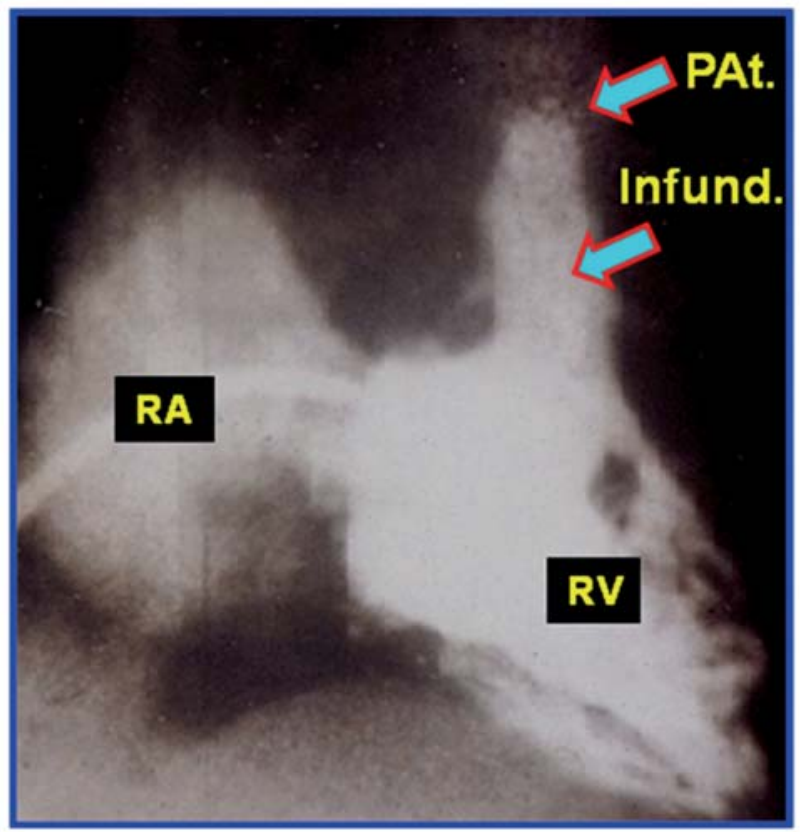

Fig. 1 - Angiographic study. Observed hypoplasic right ventricle, consisted by three segments: inlet, trabecular and infundibular portion. Observed too, pulmonary atresia and important tricuspid valve regurgitation. $R A=$ right atrium; $R V=$ right ventricle; Infund. = Infundibulum; $P A$. = pulmonary atresia etc.) (Figure 1) and 2- Function: diastolic volume, ejection fraction and contractility. Although, the anatomy and pressure of the pulmonary artery tree were studied.

The evaluation was concluded with a study of BCPS and presence of arterial and venous collateral circulation.

In patients with Ebstein's anomaly, submitted to cardiac catheterism, the RV morphology was studied, including the atrialized portion and tricuspid valve malformation followed by anatomic types of Carpentier's classification [3] and functional evaluation: uni or bi-directional shunt through atrial septal defect, RV function (mean ejection fraction, shortening fraction).

\section{Surgery}

All selected patients were submitted to one and a half ventricle repair, atrial septal closure and tricuspid valvuloplastic procedure. Six patients with PA - IVS had been associated to bidirectional cavopulmonary shunt (BCPS) and three patients with Ebstein's anomaly, a BCPS was performed in the same operative step (Table 1).

Six patients with PA - IVS were submitted to previous surgery which included: modified Blalock-Taussig shunt plus surgical pulmonary valvulotomy by median sternotomy approach, in the neonatal age. These six patients had the second stage with BCPS, between the ages of 1 and 3 years old. Three patients with Ebstein's anomaly had no previous operation.

Through a median sternotomy, conventional cardiopulmonary bypass with moderate hypothermia $\left(28^{\circ} \mathrm{C}\right)$ was instituted with the use of bicaval cannulation and correct multidose cold blood cardioplegia was used in all cases, after aortic cross clamping.

\section{PA-IVS}

All patients of this group were submitted to dissection of BCPS (Figure 2), superior and inferior vena cava were canulated and CPB was installed. The surgical approach was performed by right atrium (RA) and RV. The atrial septal defect (ASD) (Figure 3) was closed using preserved porcine pericardium.

Finally, one preserved porcine pulmonary prosthesis (Braile Biomédica - São José do Rio Preto, São Paulo, Brazil) was implanted for the remodeling of the RV: Pulmonary valve and RVOT reconstruction (Figure 4). The prosthesis diameter was chosen according to the Rowlatt's normogram [4].

\section{Ebstein's anomaly}

In all patients of this group the SVC and IVC were canulated and the CPB was installed. Cold blood cardioplegia was infused by aortic root. The atrial septal defect was closed in standard fashion.

The superior vena cava was divided above the area of the sino-atrial node. The cardiac end of SVC was closed 


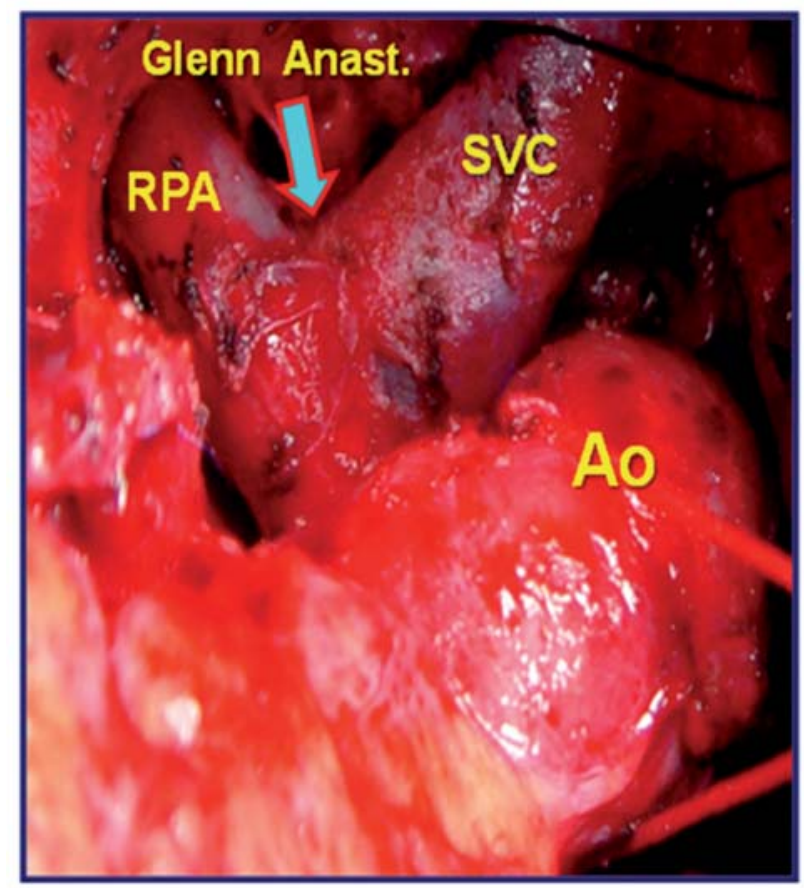

Fig. 2 - Surgical image shows dissection of cardiac structures: anastomosis between superior vena cava (SVC) and right pulmonary artery (RPA) (Bidirectional Glenn shunt). Ao = aorta; Anast $=$ anastomosis

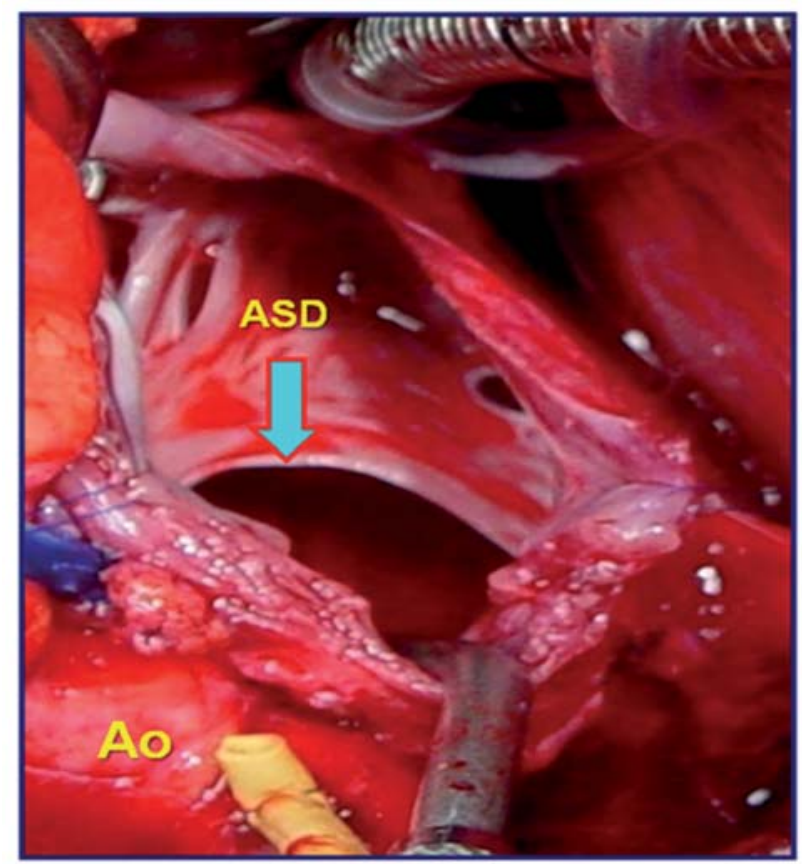

Fig. 3 - Surgical image shows: patient on cardiopulmonary bypass, after atrial approach we observed a large atrial septal defect (ASD). Ao $=$ aorta

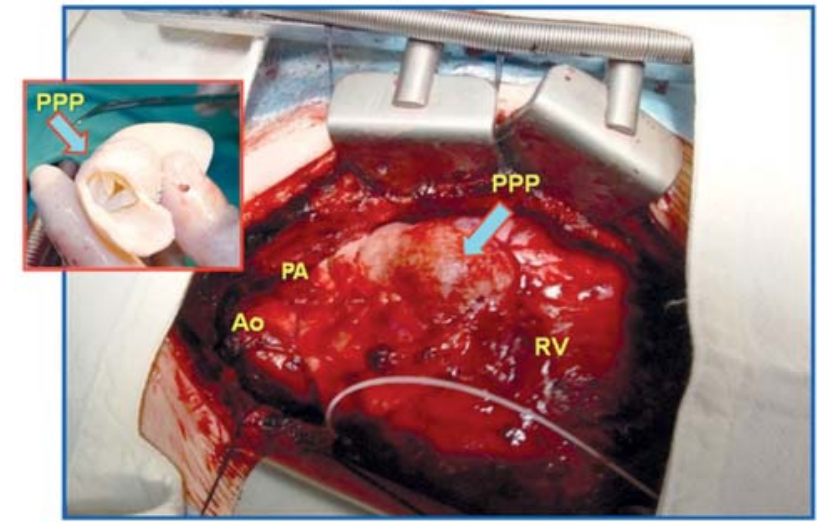

Fig. 4 - Surgical image shows: patient off cardiopulmonary bypass, porcine pulmonary prosthesis (PPP) implanted for right ventricular remodeling. Ao $=$ aorta $; P A=$ pulmonary artery; $R V=$ right ventricle; porcine pulmonary prosthesis ( $P P P)$ (detached image)

with running suture and the distal end was anastomosed at the right pulmonary artery. The cardiac defects were repaired: plicature of the atrialised portion, tricuspid valve plastic repair, employing the Carpentier's procedure (rotation of the anterior leaflet) and closure of the ASD. one patient was submitted to reconstruction of the RVOT with preserved pulmonary heterograft (Table 2). Finally, patients were rewarmed and cardiopulmonary bypass was discontinued.

Table 2. Operative procedure: one a half ventricle operation.

\begin{tabular}{lc}
\hline Procedure & Patients \\
& $\mathrm{N}(\%)$ \\
\hline ASD closure & $9(100 \%)$ \\
RVOT reconstruction & $7(77.7 \%)$ \\
Preserved pulmonary heterograft & $7(77.7 \%)$ \\
Tricuspid valve plastic & $3(33.3 \%)$ \\
\hline
\end{tabular}

$A S D=$ atrial septal defect; $R V O T=$ right ventricle outlet tract

\section{Postoperative care}

All patients left the operating room with a left atrial line and SVC line. Their values were continuously monitored until stabilization. Early extubation was performed in the operating room if possible or in the Pediatric Intensive Care Unit (PICU) during the first postoperative day. Mild inotropic support was typically given in the form of dobutamine $\left(5 \mu \mathrm{g} \mathrm{kg}{ }^{-1} \mathrm{~min}^{-1}\right)$. Nitric oxide was used in special cases.

\section{Statistical analysis}

All values of continuous variables were expressed as mean and range. Comparisons between variables were performed with the Student's $t$ test. 


\section{RESULTS}

\section{Patients characteristics and clinical results}

There was one hospital deaths (11.1\%): patient with Ebstein's anomaly presented LV dysfunction after operative correction and it was maintained in circulatory assistance during $48 \mathrm{~h}$, without success.

Eight patients were discharged in good clinical conditions and at mean follow-up of 28.7 months (range 11 months to 9.3 years). In all there was complete regression of the cyanosis and of the signs of heart failure. During late follow-up the echocardiographic exam showed reduced degree of tricuspid regurgitation (2/4) and preserved right and left ventricular function. One patient with PA w/ IVS presented aneurismatic dilatation of the pulmonary heterograft associated to pulmonary valve insufficiency. This patient was reoperated in the $4^{\text {th }}$ year of follow-up and submitted to pulmonary heterograft substitution. This patient died (late mortality: $12.5 \%$ ) in the $2^{\text {nd }}$ postoperative period after left ventricle dysfunction (Table 3 ).

Table 3. Surgical results.

\begin{tabular}{lcc}
\hline Patients & \multicolumn{2}{c}{ Patients } \\
& $\mathrm{N}^{\circ}$ & $\begin{array}{c}\text { Mortality } \\
(\%)\end{array}$ \\
\hline Hospital mortality: & & \\
PA - IVS & - & $(33.3)$ \\
Ebstein's Anomaly & 1 & \\
Late mortality & 1 & $(12.5)$ \\
PA- IVS* & - & - \\
Ebstein's Anomaly
\end{tabular}

*Patient dead after reoperation; PA - IVS: pulmonary atresia with intact ventricular septum

\section{Follow-up}

All patients underwent clinical evaluations, oxygen saturation measurements. Six patients were in NYHA class I and two in NYHA class II. The Doppler- echocardiographic study showed good LV function, absent or mild tricuspid and pulmonary valve regurgitation and a pulsatil antegrade flow across the pulmonary valve in all. SVC Doppler evaluation, showed in all a systolic reverse flow simultaneous to the RV ejection and an antegrade flow during the rest of the cardiac cycle.

Two patients underwent cardiac catheterization 1 and 3 years after the procedure. Exercise tests (functional capacity for age) were performed 2 years after the operation in patients older than 6 years. One patient presented pulmonary artery stenosis and aneurismatic dilatation of the porcine prosthesis was submitted to prostheses substitution.

The follow-up of seven survival patients was performed with clinical evaluation, serial Doppler-echocardiogram and CT angiography 3D (Figures 5 and 6).

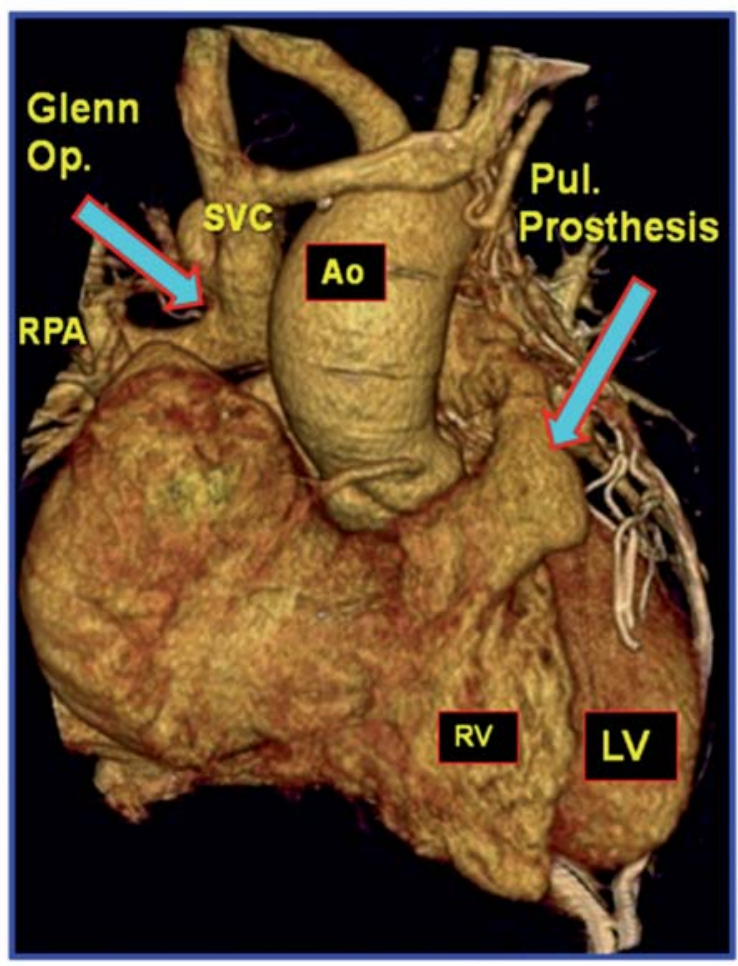

Fig. 5 - Postoperative CT angiography 3D reconstruction showing: Glenn operation and pulmonary prosthesis implanted. Ao = aorta; $R P A=$ right pulmonary artery; $R V=$ right ventricle; $L V=$ left ventricle; $S V C=$ superior vena cava

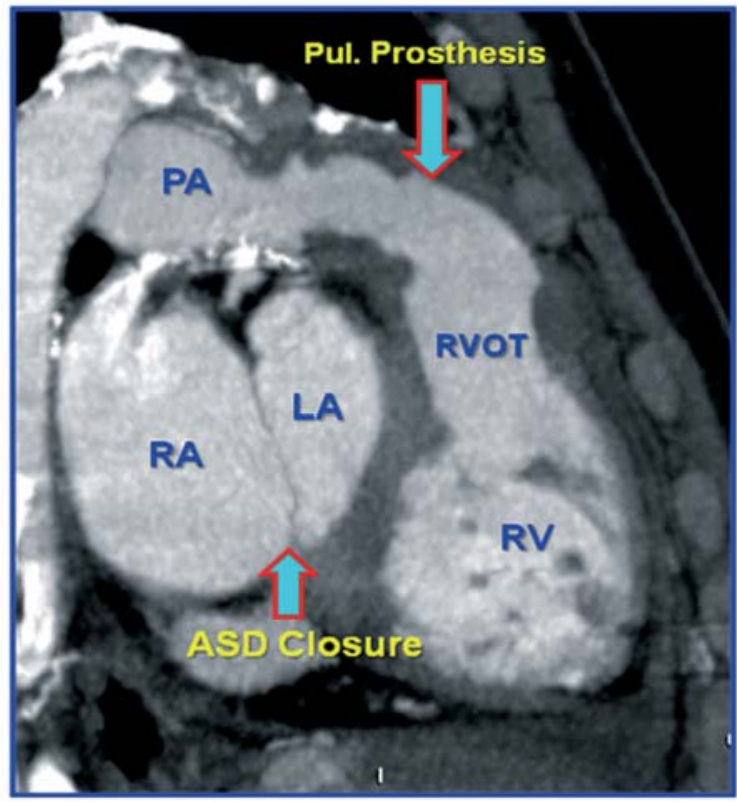

Fig. 6 - Postoperative CT angiography with contrast showing: reconstruction of the right ventricle outlet tract (RVOT) with pulmonary prosthesis. $P A=$ pulmonary artery; $R V=$ right ventricle; $L A=$ left atrium; $R A=$ right atrium; $A S D=$ atrial septal defect 


\section{DISCUSSION}

The biventricular surgical correction of cardiac malformations is the ideal objective to offer for the patient's quality of life; but there are situations in which the RV may be inadequate to convey the entire cardiac output to the pulmonary circulation, because of its cavity size and/or function.

The one and-a-half ventricular repair is used when there is essentially a single functional ventricle and the dysfunctional RV, although not considered of sufficient size, greater than $50 \%$ as well as annular diameter of the tricuspid valve, greater than $70 \%$ of the anticipated normal values, to handle an entire cardiac output, is considered to be of sufficient size to handle about half or $2 / 3$ of the cardiac output.

One and a half ventricular repair is a surgical option for congenital cardiac anomalies characterized by a hypoplastic but potentially or partially usable right ventricle. In the hemodynamic physiology of this circulation, the SVC is in series with the pulmonary artery, the lungs are also important in Fontan circulation [5].

In order to determine whether of one and a half ventricular repair is definitely superior to the Fontan procedure in patients having hypoplastic RV in the setting of PA/IVS or Ebstein's anomaly, only the results in the long term will determine.

Patients with Ebstein's anomaly, before surgical correction can present after childhood or adolescence: cyanosis, arrhythmias, severe right ventricular or left ventricular dysfunction secondary to the prolonged cyanosis after right ventricular interference. At this point conventional anatomical repair, for many times, is accompanied by elevated morbidity or mortality and poor functional results.

Recent report [6] showed the experience with three patients with Ebstein's anomaly, very dilated right atrium, severe tricuspid valve regurgitation and bi-directional shunt through an atrial septal defect and reduced left ventricular function.

All patients underwent one and a half ventricular repair consisting of closure of the atrial septal defect, tricuspid repair with reduction of the atrialized portion of the right ventricle and end-to-side anastomosis of the superior vena cava to the right pulmonary artery.

All patients survived, with a mean follow-up of 33 months. In all there was complete regression of the cyanosis and of the signs of heart failure. Postoperative echocardiography showed reduced degree of tricuspid regurgitation (2/4) and improvement of the left ventricular function and mean shortening fraction.

In our limited experience and intermediate time of followup with one and a half ventricle repair, it can be achieved with a very low surgical risk, even in the presence of associated complex congenital cardiac anomalies (PA - IVS and Ebstein's anomaly). We are convinced that the surgical strategy for this surgical option needs to be planned in detail before the repair, as we did in our experience. We have one death in the Ebstein's group, due to left ventricle dysfunction after acute cardiac arrhythmia, in the early postoperative period; two surviving patients are in functional class I (NYHA).

Stellin et al. [7] refer that patients underwent repair of PA-IVS by means of a RVOT prosthesis reconstruction after a pulmonary valvotomy and central systemic-to-pulmonary artery shunt, in adjunct to a BCPS we performed a valve TV commissurotomy and papillary muscle splitting. In fact, to a hypoplastic TV annulus ( $Z$ value, - 4.3) we have found that a thick and sclerotic subvalvar apparatus was further limiting the blood inlet to the RV. Papillary muscles splitting as far down as the RV wall allowed a better movement of the tensor apparatus, improving the leaflets excursions and therefore the valve performance. There is only a mild TV incompetence at the follow-up echocardiographic control.

Since the introduction of the bidirectional Glenn shunt in the later 1980s, this palliative procedure has increased in popularity among cardiac surgeons around the world. In recent years, however, words of caution have emerged regarding the bidirectional Glenn shunt.

In our Institution, following the Great Ormond Street Hospital's behavior [8], the total cavopulmonary connection is performed in staged strategy: in March 1990, we performed the $1^{\text {st }} \mathrm{BDG}\left(1^{\text {st }}\right.$ stage $)$ and in April, 1992 the same patient was completed to TCPC ( $2^{\text {nd }}$ stage), with good results [9].

This successful technique was adopted, rapidly, by Institutions with Pediatric Cardiovascular Surgery, all over the Country [10-15].

An adjustable fenestration was used in selected cases. The decision to leave the fenestration open was based on postoperative hemodynamics. The presence of a right atrial pressure greater than $15 \mathrm{mmHg}$ was considered an indication for opening the fenestration. A transatrial gradient of more than $10 \mathrm{mmHg}$ was considered an additional indication.

In our series, no patient was submitted to right pulmonary artery banding, proposed by Kreutzer et al. [16]; these authors referred that patients with previous pulmonary valve incompetence or in those who required trans-annular patches or right ventricle-pulmonary artery conduits as part of their concomitant cardiac repair, a slight banding of the right pulmonary artery between the bidirectional Glenn shunt and its origin was carried out to prevent excessive pulsate wave, defined as differential pressure of more than $5 \mathrm{mmHg}$, and to impede SVC flow to the right ventricle. 
The BDG is indicated to very young patients (1 to 2 years) and the TCPC is indicated to 2-3 years later. In patients with PA-IVS and Ebstein's anomaly with hypoplastic RV, is possible to take advantage of the contractility of the RV and pulsated pulmonary blood flow.

This conduct is considered to be one of the most important factors for achieving excellent clinical results when selecting a staged strategy to treat high-risk Fontan candidates. The most significant findings to indicate the Fontan procedure in staged operation are: 1- The volume-load reduction of the systemic ventricle resulted in improvement in contractility both after BDG and after staged TCPC; 2- Afterload increased both after BDG and after staged TCPC and 3- These changes resulted in improvement of ventricular efficiency during the interval period between BDG.

The Royal Brompton Hospital group of London published [17] the surgical results of three patients previously undergoing one and one-half ventricular repair, right ventricular dysfunction progressed for more than 10 years. Their clinical features resembled those seen in patients undergoing the atriopulmonary Fontan procedure, and reoperation was carried out for conversion to total cavopulmonary connection. Hemodynamics improved subsequent to the circulatory renewal. In two patients having atrial arrhythmia before conversion, the resected right atrial wall illustrated grossly abnormal histopathology. These patients suffered from persistent sinus nodal dysfunction and eventually needed pacemaker implantation. The third patient died of sepsis 4 months later.

The major concern in the extended application of one and a half ventricular repair is the currently limited knowledge of the long term results, due to the relatively recently utilization of this surgical approach and to the reduced number of clinical reports in this regard [18].

In order to collect as much information as possible on potential indications, early and long term results, it was created an "International Registry for One and a Half Ventricular Repair”. The Registry was officially announced at the last World Congress of Pediatric Cardiology and Cardiac Surgery in Toronto, in 2001. Only data collection and analysis of a large number of patients will allow better clarification of the possibilities offered by one and a half ventricular repair and therefore facilitate future decisionmaking progress with regard to this promising surgical approach, including patients with Ebstein's anomaly.

\section{CONCLUSIONS}

In our series of patients with PA-IVS and Ebstein's anomaly, submitted to one and a half ventricle repair:

1. The procedures were performed with an acceptable risk and it is possible to take advantage of the contractility of the RV and pulsated pulmonary blood flow.
2. Patients with tripartite right ventricles demonstrated a tendency to adequate performance handling the IVC flow and toward enlargement of the pulmonary ventricular chamber with somatic growth.

\section{REFERENCES}

1. Billingsley AM, Laks H, Boyce SW, George B, Santulli T, Williams RG. Definitive repair in patients with pulmonary atresia and intact ventricular septum. J Thorac Cardiovasc Surg. 1989;97(5):746-54.

2. Hanley FL, Sade RM, Blackstone EH, Kirklin JW, Freedom RM, Nanda NC. Outcomes in neonatal pulmonary atresia with intact ventricular septum. A multiinstitutional study. J Thorac Cardiovasc Surg. 1993;105(3):406-23.

3. Carpentier A, Chauvaud S, Macé L, Relland J, Mihaileanu S, Marino JP, et al. A new reconstructive operation for Ebstein's anomaly of the tricuspid valve. J Thorac Cardiovasc Surg. 1988;96(1):92-101.

4. Rowlatt JF, Rimoldi JHA, Lev M. The quantitative anatomy of the normal child's heart. Pediatr Clin North Am. 1963;10:499.

5. Hanley FL. The one and a half ventricle repair: we can do it, but should we do it? J Thorac Cardiovasc Surg. 1999;117(4):659-61.

6. Corno AF, Chassot PG, Payot M, Sekarski N, Tozzi P, Von Segesser LK. Ebstein's anomaly: one and a half ventricular repair. Swiss Med Wkly. 2002;132(33-34):485-8.

7. Stellin G, Vida VL, Milanesi O, Rubino M, Padalino MA, Secchieri S, et al. Surgical treatment of complex cardiac anomalies: the 'one and one half ventricle repair'. Eur J Cardiothorac Surg. 2002;22(3):431-6.

8. de Leval MR, Kilner P, Gewillig M, Bull C. Total cavopulmonary connection: a logical alternative to atriopulmonary connection for complex Fontan operations. Experimental studies and early clinical experience. J Thorac Cardiovasc Surg. 1988;96(5):682-95.

9. Maluf MA, Andrade JCS, Catani R, Carvalho AC, Negrini N, Buffolo E. Avaliação dos resultados tardios da operação de derivação cavo-pulmonar bidirecional, no tratamento paliativo de cardiopatias congênitas com câmara ventricular única. Rev Bras Cir Cardiovasc. 1994;9(2):95-103.

10. Fantini FA, Gontijo Filho B, Martins C, Lopes RM, Heiden E, Vrandecic E, et al. Cirurgia de Glenn bidirecional: importância da manutenção de fluxo "pulsátil" na artéria pulmonar. Rev Bras Cir Cardiovasc. 1995;10(1):25-33. 
11. Pinto WC, Carvalho W, Barroso HB, Mejia JAC, Mesquita FA, Sardenberg CR, et al. Anastomose cavo-pulmonar total sem uso de material protético. Rev Bras Cir Cardiovasc. 1998;13(3):67-72.

12. Gontijo Filho B, Fantini FA, Lopes RM, Martins C, Castro MF, Drumond LF, et al. Resultados a médio prazo da anastomose de Glenn bidirecional. Rev Bras Cir Cardiovasc. 1999;14(1):39-45.

13. Westphal FL, Maluf MA, Silva CMC, Carvalho AC, Buffolo E. Estudo angiográfico comparativo da artéria pulmonar no pré e pós-operatório de pacientes submetidos a operação de derivação cavopulmonar bidirecional. Rev Bras Cir Cardiovasc. 2001;16(4):305-20.

14. Fonseca L, Silva JP, Franchi SM, Castro RM, Comparato DO, Baumgratz JF. Operação de Glenn bidirecional no tratamento estagiado da síndrome de hipoplasia do coração esquerdo: resultados imediatos e tardios. Rev Bras Cir Cardiovasc. 2005;20(1):34-7.

15. Fantini FA, Gontijo B, Martins C, Lopes RM, Vrandecic EC, Goulart E, et al. Operação de Fontan: uma técnica em evolução. Rev Bras Cir Cardiovasc. 2009;24(4):154-7.

16. Kreutzer C, Mayorquim RC, Kreutzer GO, Conejeros W, Roman MI, Vasquez H, et al. Experience with one and a half ventricle repair. J Thorac Cardiovasc Surg. 1999;117(4):662-8.

17. Uemura H, Yagihara T, Adachi I, Kagisaki K, Shikata F. Conversion to total cavopulmonary connection after failed one and one-half ventricular repair. Ann Thorac Surg. 2007;84(2):666-8.

18. Miyaji K, Shimada M, Sekiguchi A, Ishizawa A, Isoda T, Tsunemoto M. Pulmonary atresia with intact ventricular septum: long-term results of "one and a half ventricular repair". Ann Thorac Surg. 1995;60(6):1762-4. 